\title{
The prevalence of diabetes among tuberculosis patients in Denmark
}

\author{
Franziska Grundtvig Huber ${ }^{1,2^{*}}$, Kristina Langholz Kristensen ${ }^{3}$, Inge Kristine Holden ${ }^{4}$, Peter Henrik Andersen ${ }^{5}$, \\ Banoo Bakir ${ }^{2,9}$, Anja Jørgensen ${ }^{2,5}$, Hans Johan Niklas Lorentsson ${ }^{2,6}$, Karen Bjorn-Mortensen ${ }^{2,7}$, \\ Isik Somuncu Johansen ${ }^{4,8}$ and Pernille Ravn ${ }^{2}$
}

\begin{abstract}
Setting: It is estimated that 25\% of the world's population are infected with Mycobacterium tuberculosis and that 463 million people are living with diabetes mellitus (DM), a number that is increasing. Patients with DM have three times the risk of developing tuberculosis (TB) and there is significant interaction between DM and TB, suggesting that DM affects not only risk of TB but also TB presentation, treatment response and outcome.
\end{abstract}

Objective: The aim was determining the prevalence of DM among TB patients in Denmark and to assess risk factors.

Design: Patient files from all notified TB cases in Denmark from 2009 to 2014 were retrospectively assessed.

Results: In total, 1912 patients were included and 5.0\% had DM. Patients with DM were older, had more comorbidities, came from outside Denmark, and had a higher mortality compared to non-DM-patients. None of the patients from Greenland had DM. Patients with low socio-economic status had a low prevalence of DM. We found a higher prevalence of DM among Danish-born $<54$ year and migrant $\geq 75$ year compared to a Danish background population.

Conclusion: We found a higher prevalence of DM among TB patients with known risk factors, and a surprisingly low prevalence among patients with low socioeconomic status and patients from Greenland.

Keywords: Tuberculosis, Diabetes, Greenland, Denmark, Risk factors

\section{Introduction}

Tuberculosis (TB) is one of the deadliest infectious diseases worldwide, with $25 \%$ of the population worldwide infected by Mycobacterium tuberculosis. It is estimated that 10 million people develop TB each year and over 1.5 million die from TB $[1,2]$. Since 2000, TB mortality has decreased by $27 \%$ [1]. Diabetes mellitus (DM) incidence is rising worldwide. In 2019 it was estimated that 463 million people were living with DM and projections of the rise in DM prevalence are alarming [3].

*Correspondence: Franziska.grundtvig@gmail.com

${ }^{1}$ Zealand University Hospital, Køge, Denmark

Full list of author information is available at the end of the article
The association between TB and DM is well established. Already in 1947 one study described that almost $50 \%$ of patients with DM developed pulmonary TB and patients with poor diabetic control were more likely to develop active TB [4]. More recent studies estimate that approximately $15 \%$ of new TB cases could be attributed to DM [5-8]. One systematic review found that patients with DM had three times increased risk of TB regardless of background TB incidence, study region, and study design [9]. Patients with DM and TB are more likely to have severe symptoms, higher mortality, higher risk of relapse and longer sputum conversion time to normal compared with patients without DM [10-13]. DM is described by the World Health Organisation as a neglected, important and re-emerging risk factor for $\mathrm{TB}$ 
$[1,14]$. It is expected that almost $80 \%$ of global adult DM cases occur in developing countries and the convergence of these two epidemics may lead to an increase in incidence of TB [15]. In Denmark, most patients with TB come from regions with high prevalence of $\mathrm{DM}$, but data on the burden of DM among TB patients in Denmark is limited. To our knowledge, only one study has been conducted among a Danish population addressing the prevalence of TB among DM patients. The present study, in contrast, aims to determine the prevalence and risk factors of DM among patients with TB in Denmark.

\section{Methods}

\section{Study population and study area}

The study was carried out as a nationwide retrospective register-based cohort study including all adult patients ( $>18$ years) notified with TB in Denmark from January 1st 2009 to December 31st 2014. The population has been previously described in detail by Holden et al. [16]. In brief, all medical records were reviewed for sociodemographics, clinical characteristics, diagnosis, treatment of TB and outcome. Patients were diagnosed with TB by a positive microscopy, polymerase chain reaction (PCR) or sputum culture. Both patients with pulmonary TB (PTB) and extrapulmonary TB (ETB) were included in the study. We did not have access to individual information on drug-resistance. Patients under the age of 18 years were excluded from the study. If a patient did not have a valid CRP number which gave us access to information on comorbidities through National patients register (LPR) they were excluded. Some patients were registered with more than one TB diagnosis, only the first reported TB incident was included in the study.

\section{Ethical approval}

The study was carried out in accordance with the STROBE guidelines and regulations and approved by the Danish Patient Safety Authority (3-3013-2531/1) and the Danish Data Protection Agency (VD-2018-180 and 18/40838). In accordance with Danish law, observational studies performed in Denmark do not need approval from the Danish Ethics Committee or written consent from patients (Danish Scientific Ethical Committee Act $\$ 14)$. All analyses are presented anonymously.

\section{Data collection}

In Denmark, TB is monitored by the Department of Infectious Epidemiology and Prevention at Statens Serum Institut (SSI) and TB cases were retrieved from there. All culture-based analysis is performed here. We chose the first time of diagnosis for patients registered with multiple $\mathrm{TB}$ registration dates.
Information on baseline characteristics, risk factors, and mortality were obtained from patient records. Information on region of origin was retrieved from the Department of Infectious Disease Epidemiology and Prevention, SSI and information on comorbidities was obtained from the National Patients Register in form of a Charlson Comorbidity Score [17] based on patients discharge diagnoses. Migrant status was defined as patients born abroad or those born in Denmark for whom one or both parents had been born abroad, including patients or parents born in Greenland.

Sociodemographic information was collected from medical records, and excessive use of alcohol was quantified according to the Danish Health Authorities recommendations. A patient was registered as having DM if they had an ICD10 diagnose code of DM or if it was mentioned in the patient record that the patient had diabetes. In Denmark a patient is diagnosed with DM if they have a random blood sugar measurement of $>11.1 \mathrm{mmol} / \mathrm{L}$, a fasting blood sugar measurement $>7 \mathrm{mmol} / \mathrm{L}$ or if a patient has a $\mathrm{HbA} 1 \mathrm{c}$ measurement of $>48 \mathrm{mmol} / \mathrm{mol}$, or an impaired oral glucose tolerance test.

\section{Statistics}

Data were described as count (\%) for categorical variables and mean [standard deviation (sd)] or median [interquartile range (IQR)] for continuous variables. $x^{2}$ and t-test were used to describe differences between different groups of patients as appropriate. Risk factors for known DM were assessed using logistic regression and multiple logistic regression (causal-based approach). A p-value $<0.05$ was considered statistically significant. Data were analysed using R Studio (Version 1.1.456 and version 1.2.5042).

\section{Results}

In total, 2131 patients were registered with $\mathrm{TB}, 137$ were $<18$ years old and 82 had incomplete data or could not be found in the registers and were excluded (Fig. 1). Thus, 1912 patients with TB were included in the analysis, 668 (34.9\%) were born in Denmark, 452 (23.6\%) in Asia, 346 (18.1\%) in Greenland, 249 (13.0\%) in Africa, 195 (10.2\%) in Europe outside Denmark and 11 (0.57\%) came from either North- or South America (Table 1). We found an overall DM prevalence of $5.0 \%(n=96)$. The prevalence of DM remained relatively stable through the study period, ranging from $4.3 \%$ in 2009 to $5.0 \%$ in 2014 .

The DM prevalence among Danish-born TB patients was $6.1 \%$, among $\mathrm{TB}$ patients from the rest of Europe 7.7\%, and in patients from Asia and Africa 5.3\% and 6.4\%, respectively. No TB patients from Greenland, South America, or North America had a DM diagnosis (Table 1). 


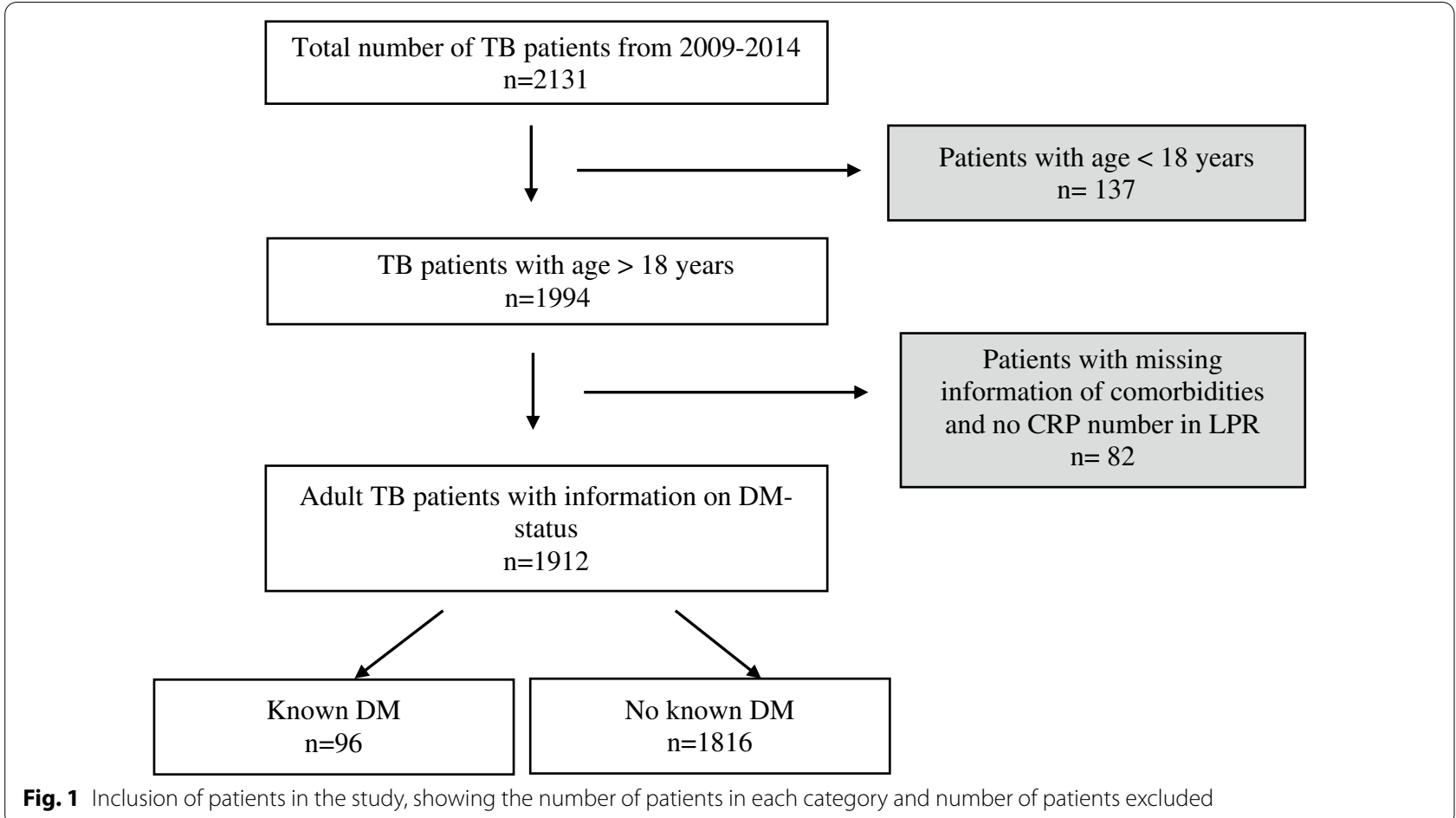

Table 1 Percentage of TB patients with known DM according to countries or regions of origin

\begin{tabular}{lccc}
\hline & Total number of patients with TB & $\begin{array}{l}\text { Number of patients with TB and } \\
\text { DM }\end{array}$ & $\begin{array}{l}\text { Percentage of patients } \\
\text { with TB and DM (\%) }\end{array}$ \\
\hline Denmark & 668 & 41 & 6.14 \\
Europe-outside Denmark & 195 & 15 & 7.7 \\
Africa & 249 & 16 & 6.4 \\
Asia & 452 & 24 & 5.3 \\
Greenland & 346 & 0 & 0.0 \\
North America & 5 & 0 & 0.0 \\
South America & 6 & 0 & 0.0 \\
Total & 1912 & 96 &
\end{tabular}

\section{Characteristics for TB patients stratified by DM status}

TB patients with DM were significantly older than TB patients without DM, had a higher Charlson Comorbidity Score and had a much higher mortality $(17.7 \%$ versus $6.8 \%)(\mathrm{p}<0.01)$ (Tables 2 and 3). In contrast, patients with $\mathrm{DM}$ were less likely to be homeless, have excess use of alcohol, smoke cigarettes or use cannabis $(\mathrm{p}<0.01)$.

The prevalence of DM among Danish-born TB patients was stratified by sex and age groups and compared with the DM prevalence in the background population in Denmark in $2012^{1}$ (Fig. 2).

The prevalence of DM among younger TB patients was generally low. Although, young Danish-born TB patients seemed to have a higher prevalence of DM compared to the background population in Denmark (Fig. 2). We found that the prevalence among Danish-born male TB patients aged $<35-54$ ranged between $3.2 \%$ and $6.2 \%$, compared to $1.7 \%$ and $4.6 \%$ in the background population. Among Danish-born women $<45$ years the DM

\footnotetext{
${ }^{1}$ Flachs EM, Eriksen L, Koch MB, Ryd JT, Dibba E, Ettrup L, Juel K. Statens Institut for Folkesundhed, Syddansk Universitet. Sygdomsbyrden i Danmark sygdomme. København: Sundhedsstyrelsen; 2015.
} 
Table 2 Baseline characteristics for TB-patients stratified by DM status

\begin{tabular}{|c|c|c|c|c|c|}
\hline \multirow[t]{2}{*}{ Patients } & \multicolumn{2}{|c|}{ Known DM $(n=96)$} & \multicolumn{2}{|c|}{ No known DM $(n=1816)$} & \multirow[t]{2}{*}{ p-value } \\
\hline & $\mathbf{n}$ & $\%$ & $\mathbf{n}$ & $\%$ & \\
\hline Age, median (IQR) & \multicolumn{2}{|l|}{$57.0(47 ; 70)$} & \multicolumn{2}{|l|}{$44.0(32 ; 54)$} & $<0.01$ \\
\hline \multicolumn{6}{|l|}{ Sex } \\
\hline Male & 65 & 67.7 & 1125 & 61.9 & 0.31 \\
\hline \multicolumn{6}{|l|}{ Socio-economic factors } \\
\hline Homeless & 4 & 4.2 & 194 & 10.7 & $<0.01$ \\
\hline Prison & 0 & 0 & 34 & 1.9 & 0.24 \\
\hline Alcohol use & 19 & 19.8 & 671 & 36.9 & $<0.01$ \\
\hline Narcotics use & 7 & 7.3 & 155 & 8.5 & 0.81 \\
\hline Cannabis use & 5 & 5.2 & 357 & 19.7 & $<0.01$ \\
\hline Tobacco use & 41 & 42.7 & 1074 & 59.1 & $<0.01$ \\
\hline \multicolumn{6}{|l|}{ Country or region of origin } \\
\hline Denmark & 41 & 42.7 & 627 & 34.5 & 0.13 \\
\hline Africa & 16 & 16.7 & 224 & 12.3 & 0.28 \\
\hline Europe & 15 & 15.6 & 180 & 9.9 & 0.10 \\
\hline Asia & 24 & 25.0 & 428 & 23.6 & 0.84 \\
\hline Greenland & 0 & 0.0 & 346 & 19.1 & $<0.01$ \\
\hline North or South America & 0 & 0.0 & 5 & 0.3 & 1 \\
\hline & 0 & 0.0 & 6 & 0.3 & 1 \\
\hline \multicolumn{6}{|l|}{ Type of TB } \\
\hline Pulmonary TB & 74 & 77.1 & 1420 & 78.2 & 0.90 \\
\hline Extrapulmonary TB & 22 & 22.9 & 396 & 21.8 & 0.90 \\
\hline TB $>1$ site & 10 & 10.4 & 97 & 5.3 & 0.06 \\
\hline \multicolumn{6}{|l|}{ Outcome } \\
\hline Mortality & 17 & 17.7 & 124 & 6.8 & $<0.01$ \\
\hline
\end{tabular}

prevalence ranged from 2.7 to $5.4 \%$ compared to $1.7-2.3 \%$ in the background population. The two cohorts are not directly comparable, and we did not attempt to analyse statistically significant differences, but the findings could indicate an almost two times increased risk of DM among young TB patients of similar age and sex compared to the background population. Among migrants, we saw a high prevalence of DM among older patients of up to almost $39 \%$ among patients aged $>65$ years (data not shown). In contrast, Danish-born TB patients $\geq 65$ years did not have a higher DM prevalence compared to the Danish background population.

\section{Risk factors for DM}

Risk factor analysis for having DM among TB patients is shown in Table 4. Age above 40 years was statistically significant in both crude (OR $3.5[2.12 ; 6.18] \mathrm{p}<0.01)$ and multivariable analyses (OR $3.49[2.09 ; 6.11] \mathrm{p}<0.01)$ while parameters associated with low socioeconomic status (homelessness, alcohol use, cannabis use, tobacco use) were associated with lower risk of DM (Table 4). Being from another European country than Denmark, from Africa or from Asia was statistically significantly associated with having DM in the multivariable analysis, whereas none of the patients from Greenland had DM and the OR could not be calculated.

\section{Discussion}

We found an overall prevalence of DM of 5.0\% among TB patients in Denmark. The prevalence among Danish-born TB patients was $6.1 \%$. Young Danish-born TB patients seemed to have a higher prevalence of DM compared to an age and sex matched Danish background population and a high proportion, up to $39 \%$, of older migrant TB patients had DM. Age over 40 years and being from Africa, Europe outside Denmark, or Asia were risk factors for having DM, whereas being from Greenland was not. Factors related to low socio-economic status were associated with not having DM.

The DM prevalence ranged from $0 \%$ among patients from Greenland, $6.1 \%$ among patients from Denmark to $7.7 \%$ among patients from Europe, outside Denmark. The prevalence of $6.1 \%$ among Danish-born was slightly higher than the estimated prevalence of $4.9 \%$ among 
Table 3 Comorbidities among DM and non-DM patients

\begin{tabular}{|c|c|c|c|c|c|}
\hline \multirow[t]{2}{*}{ Comorbidities } & \multicolumn{2}{|c|}{$\begin{array}{l}\text { Known } \\
\text { DM }\end{array}$} & \multicolumn{2}{|c|}{$\begin{array}{l}\text { No known } \\
\text { DM }\end{array}$} & \multirow[t]{2}{*}{ p-value* } \\
\hline & $\mathrm{n}$ & $\%$ & $\mathbf{n}$ & $\%$ & \\
\hline Total & 96 & 100 & 1816 & 100 & \\
\hline Myocardial infarct & 6 & 0.6 & 361 & 2.0 & $<0.01$ \\
\hline Heart failure & 12 & 12.5 & 30 & 1.7 & $<0.01$ \\
\hline Peripheral vascular disease & 10 & 10.4 & 32 & 1.8 & $<0.01$ \\
\hline Cerebral vascular disease & 15 & 15.6 & 70 & 3.9 & $<0.01$ \\
\hline Dementia & 0 & 0.0 & 5 & 0.3 & 1 \\
\hline Chronic pulmonary disease & 18 & 18.8 & 198 & 10.9 & 0.02 \\
\hline Connective tissue disease & 8 & 8.3 & 57 & 3.1 & $<0.01$ \\
\hline Ulcer disease & 10 & 10.4 & 80 & 4.4 & 0.01 \\
\hline Mild liver disease & 10 & 10.4 & 96 & 5.3 & 0.05 \\
\hline Moderate/severe renal disease & 0 & 0.0 & 36 & 2.0 & 0.23 \\
\hline Hemiplegia & 0 & 0.0 & 5 & 0.3 & 1 \\
\hline Tumour & 11 & 11.5 & 78 & 4.3 & $<0.01$ \\
\hline Leukaemia & 0 & 0.0 & 5 & 0.3 & 1 \\
\hline Lymphoma & 1 & 1.0 & 9 & 0.5 & 1 \\
\hline Moderate/severe liver disease & 4 & 4.2 & 10 & 0.6 & $<0.01$ \\
\hline Metastatic/solid tumour & 0 & 0.0 & 6 & 0.3 & 1 \\
\hline AIDS & 2 & 2.1 & 40 & 2.2 & 1 \\
\hline \multicolumn{6}{|l|}{ Charlson Comorbidity Score n, (\%) } \\
\hline $0-1$ & 59 & 6.2 & 1561 & 85.9 & $<0.01^{* *}$ \\
\hline $2-3$ & 23 & 23.9 & 174 & 9.6 & $<0.01$ \\
\hline $4-5$ & 8 & 8.3 & 34 & 1.9 & $<0.01$ \\
\hline$=>6$ & 5 & 5.2 & 47 & 2.6 & 0.18 \\
\hline
\end{tabular}

${ }^{*} \mathrm{p}$-value from Chi-square test

** $p$-value $<0.05$ was considered significant, when comparing the percentage of DM patients and no-DM patients stratified by Charlson Comorbidity Score

the Danish background population [18]. The risk of TB among patients with DM in Denmark has been addressed in a register-based population study [19] showing a high rate ratio (RR) of TB (RR: $1.9,95 \%$ CI [1.7-2.1]) among DM patients compared to non-DM patients. In contrast to our study, they found a low RR (0.5) for having TB among African DM patients when stratifying for ethnicities. The apparent differences could be explained by differences of age, study design and study period.

The DM prevalence among older migrants was as expected higher compared to the Danish patients. This is in line with studies from Africa, Asia, and countries such as Mexico, reporting prevalences of DM among TB patients ranging from 5\% to up to 50\% [20-23]. Interestingly, these studies found that the DM prevalence among TB patients was not only high, but also higher than in the background population. The high prevalence not only reflects the high burden of DM in the areas, it also underlines the possible interaction between the two diseases where DM and poor glycaemic control compromise innate and adaptive immunity and enhance susceptibility to TB $[23,24]$.

The finding that the prevalence of DM among migrant TB patients was highest in the old age groups could be related to the fact that DM is associated both with age and the fact that many patients migrated from DM high-endemic regions and therefore had a higher risk of DM compared to the Danish patients. Also, older TB patients also had more comorbidities and therefore also had more contact with the health-care system allowing them to be diagnosed with DM [26].

In contrast the lower than expected prevalence in the young migrant TB patients could be due to differences in health seeking behaviour explained by cultural differences, language barriers or social problems such as homelessness and substance abuse or the fact that they were newly immigrants to Denmark. Patients from Greenland were included in the migration-group, in the assessment of age, sex and DM in Fig. 2.

In our study, younger Danish-born women (3544 years of age) and men (35-54 years of age) had almost two times higher prevalence of DM compared to an age matched background population. This was an unexpected finding, and even though the numbers are small and the two cohorts are not directly comparable, one should be aware of the possible interactions in younger individuals, and patients with undiagnosed DM and pre-DM may be at risk of complications to DM if undiagnosed and untreated. Together these findings emphasize the need for DM screening of TB patients even in a low incidence country as Denmark. Danish guidelines for TB $[25,27]$ focus on this matter by recommending screening of TB patients for DM and suggest treatment of latent $\mathrm{TB}$ infection in individuals from high $\mathrm{TB}$ endemic regions with compromised immunity including DM.

In Denmark, TB is frequently seen among individuals from Greenland where the incidence of TB is high [28]. We found no patients with known DM among TB patients from Greenland. This is surprising, since other studies show a high (and increasing) prevalence of DM in Greenland. One study [29] found a DM prevalence of between 15 and $18 \%$ among the Inuit population in Greenland, when using an oral glucose test, and between 6.2 and $6.8 \%$, when using HbA1c. Additionally, a relative risk for TB among DM patients in Greenland of 11.7 has been reported, and DM in TB patients from Greenland would be expected to be common [30]. One reason for the low prevalence in patients from Greenland could be due to lack of knowledge of their DM status; it has previously been estimated that $70 \%$ of Greenlanders with DM were unaware of their DM status [31]. This estimate, however, is almost 20 years old and awareness of DM 


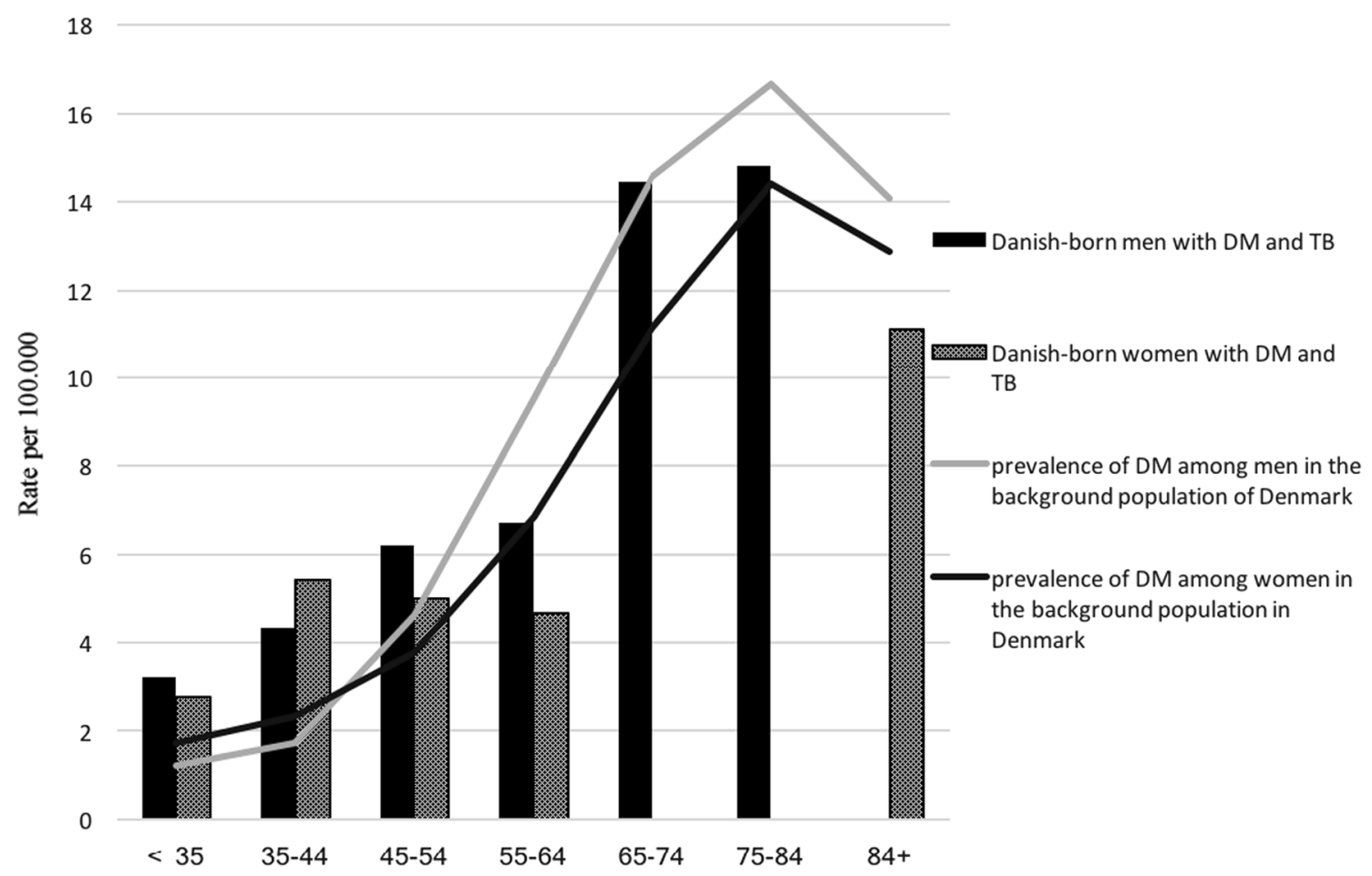

Fig. 2 Prevalence (rate per 100.000) of DM among Danish-born and migrant TB patients, compared to the prevalence in the background population of Denmark, stratified by age group and sex

both in the Greenlandic public and health care system has increased in recent years [32].

The patients from Greenland in this study had a high prevalence of homelessness, tobacco use and alcohol use. This was also true for patients from Denmark. Homelessness, tobacco use and alcohol use is associated with low socioeconomic status. These patients often experience social barriers and therefore have altered health seeking behaviour [33-36], which could be a reason why these patients were not screened for DM. Danish studies among socially marginalised individuals show a high use of both primary and secondary health care services, but only in relation to critical illness [34, 35, 37].

Thus, the low prevalence of known DM among TB patients from Greenland could be explained by low socio-economic status and result in an underestimation of the DM prevalence in Greenlanders. Since we suspect that the patients from Greenland were underdiagnosed with DM, we believe that the prevalence of DM in the migration-group was biased towards a lower prevalence than the estimated prevalence.

As a consequence of this study and the increased awareness of the potential severe outcome of TB in DM patients, we are now routinely screening all TB patients for DM with HbA1c and blood glucose at TB diagnosis in line with screening for HIV and Hepatitis. Preliminary findings showed that $1.8 \%$ were newly diagnosed with DM and that $27.3 \%$ had pre-DM with blood glucose of $>39 \mathrm{mmol} / \mathrm{mol}$ [38]. These patients are referred for treatment of DM and are informed about risk reduction and advised a control by their general practitioner.

\section{Strengths and limitations}

The major strength of this study was that we were able to identify all patients diagnosed with TB in Denmark between 2009 and 2014 due to the close TB monitoring performed by SSI and the Department of Infectious Epidemiology and Prevention.

In Denmark, TB treatment is free of charge and all patients are treated regardless of their residence status. We can thus assume that no patients opted out of treatment or were not treated due to financial reasons.

The main limitation of this study is the retrospective study design, with information gathered only from patient records and therefore we were only able to include information on DM registered in a Danish hospital medical record at the time of TB diagnosis. Thus, we have no information on DM diagnosis made after the 
Table 4 Risk factors for having DM among TB patients

\begin{tabular}{|c|c|c|c|c|}
\hline \multirow[t]{2}{*}{ Risk factor } & \multicolumn{2}{|l|}{ Crude analysis } & \multicolumn{2}{|c|}{ Multivariable analysis* } \\
\hline & OR $[95 \% \mathrm{Cl}]$ & $p$-value & OR $[95 \% \mathrm{Cl}]$ & p-value \\
\hline \multicolumn{5}{|l|}{ Age } \\
\hline Age $\leq 40$ years & 1 (Ref) & & 1 (Ref) & \\
\hline Age $>40$ years & $3.5[2.12 ; 6.18]$ & $<0.01$ & $3.49[2.09 ; 6.11]$ & $<0.01$ \\
\hline \multicolumn{5}{|l|}{ Sex } \\
\hline Female & 1 (Ref) & & 1 (Ref) & \\
\hline Male & $1.29[0.84 ; 2.02]$ & 0.26 & $1.21[0.78 ; 1.91]$ & 0.4 \\
\hline \multicolumn{5}{|c|}{ Socio-economic risk factors } \\
\hline No alcohol & 1 (Ref) & & 1 (Ref) & \\
\hline Alcohol & $0.41[0.41 ; 0.42]$ & $<0.01$ & $0.25[0.14 ; 0.42]$ & $<0.01$ \\
\hline No tobacco & 1 (Ref) & & 1 (Ref) & \\
\hline Tobacco & $0.49[0.23 ; 0.57]$ & $<0.01$ & $0.36[0.23 ; 0.57]$ & $<0.01$ \\
\hline No cannabis & 1 (Ref) & & 1 (Ref) & \\
\hline Cannabis & $0.21[0.07 ; 0.47]$ & $<0.01$ & $0.21[0.07 ; 0.47]$ & $<0.01$ \\
\hline No narcotics & 1 (Ref) & & 1 (Ref) & \\
\hline Narcotics & $0.83[0.36 ; 1.87]$ & 0.65 & $0.89[0.36 ; 1.87]$ & 0.78 \\
\hline Not homeless & 1 (Ref) & & 1 (Ref) & \\
\hline Homeless & $0.36[0.12 ; 0.88]$ & 0.05 & $0.39[0.12 ; 0.96]$ & 0.07 \\
\hline No prison time & 1 (Ref) & & 1 (Ref) & \\
\hline Prison time & $<0.01[<0.01 ;>149]$ & 0.9 & $<0.01[<0.01 ;>406]$ & 0.98 \\
\hline \multicolumn{5}{|c|}{ Country or region of origin } \\
\hline Denmark & 1 (Ref) & & 1 (Ref) & \\
\hline Europe & $1.68[0.92 ; 2.9]$ & 0.07 & $2.13[1.13 ; 3.75]$ & 0.01 \\
\hline Africa & $1.42[0.79 ; 2.41]$ & $<0.01$ & $3.3[1.7 ; 5.9]$ & $<0.01$ \\
\hline Asia & $1.08[0.66 ; 1.71]$ & 0.75 & $1.8[1.09 ; 2.99]$ & 0.02 \\
\hline Greenland** & Not applicable & - & Not applicable & - \\
\hline South America & Not applicable & - & Not applicable & - \\
\hline North America & Not applicable & - & Not applicable & - \\
\hline
\end{tabular}

*Adjusted for age, sex, not including the measured risk factor

**Due to the fact that there were no patients from Greenland with DM the OR=0.0, and p-value could not be assessed. The same was the case for North and South America

start of treatment or in other settings such as by a primary physician and our estimations of DM prevalence are most likely underestimated. Also, we did not have access to information on family status, lifestyle or how long patients had had their DM diagnosis prior to TB diagnosis, which could be a confounding issue. Since DM diagnosis was not uniformly registered, this may have resulted in the fact that some individuals may have been misclassified resulting in underestimation of the DM prevalence. We were not able to analyse the prevalence of pre-DM or dysglycemia since we did not have HbA1c levels or blood glucose on all patients. To explore the true magnitude of the DM problem among TB patients in Denmark, there is a call for prospective studies including a follow up period, where different aspects of DM, prediabetes and dysglycemia can be assessed.

\section{Conclusion}

To our knowledge this study is the first study to address the prevalence of DM among TB patients in Denmark. The prevalence of DM was slightly higher in the Danish background population and young Danish-born TB patients had an increased risk of DM, calling for follow up studies. Age over 40 years and being from Africa, Europe outside Denmark, and Asia were risk factors for having DM, whereas no patients from Greenland had known DM. Factors associated with low socio-economic status were associated with not having DM.

We find a need for prospective studies addressing the actual risk of DM and pre-DM among patients with $\mathrm{TB}$ in Denmark in order to diagnose patients at risk of DM in due time. 


\section{Abbreviations}

TB: Tuberculosis; DM: Diabetes mellitus; SSI: Statens Serum Institut; LPR: Landspatientregister; CPR: Central person register.

\section{Authors' contributions}

Study concept and design: F.G.H., P.R., K.L.K. Acquisition, analysis or interpretation of data: F.G.H., P.R., K.L.K., I.K.H., P.H.A., I.S.J. Drafting of the manuscript: F.G.H., K.L.K., P.R. Critical revision of the manuscript: K.L.K., P.R., I.K.H., B.B., A.J., H.J.N.L., K.B.M., I.S.J. Statistical analysis: F.G.H., K.L.K., P.R. Administrative and technical support: I.K.H, I.S.J, P.R., K.L.K. Supervision: K.L.K., P.R. All authors have agreed to be accountable for all aspects of the work. All authors have read and approved the final manuscript.

\section{Funding}

Not applicable.

\section{Availability of data and materials}

The dataset used and/or analysed during the current study are available from the corresponding author on reasonable request.

\section{Declarations}

\section{Ethics approval and consent to participate}

The study was approved by the Danish Patient Safety Authority (3-30132531/1) and the Danish Data Protection Agency (VD-2018-180 and 18/40838). In accordance with Danish law, observational studies performed in Denmark do not need approval from the Danish Ethics Committee or consent from patients (Danish Scientific Ethical Committee Act §14). All analyses are presented anonymously.

\section{Consent for publication}

Not applicable.

\section{Competing interests}

The authors declare that they have no competing interests.

\section{Author details}

${ }^{1}$ Zealand University Hospital, Køge, Denmark. ${ }^{2}$ Gentofte Hospital, Copenhagen, Denmark. ${ }^{3}$ Rigshospitalet, Copenhagen, Denmark. ${ }^{4}$ Odense University Hospital, Odense, Denmark. ${ }^{5}$ Statens Serum Institut, Copenhagen, Denmark. ${ }^{6}$ Steno Diabetes Center Copenhagen, Copenhagen, Denmark. ${ }^{7}$ Greenlands Center for Health Research, Ilisimatusarfik, Nuuk, Greenland. ${ }^{8}$ Mycobacteria Centre for Research Southern Denmark, Odense, Denmark. ${ }^{9}$ Department of Emergency Medicine, Nykøbing F. Hospital, Nykøbing Falster, Denmark.

Received: 29 May 2021 Accepted: 4 January 2022

Published online: 19 January 2022

\section{References}

1. WHO. Global tuberculosis report. WHO Library Cataloguing-in-Publication Data World. 2019.

2. Houben RMGJ, Dodd PJ. The global burden of latent tuberculosis infection: a re-estimation using mathematical modelling. PLoS Med. 2016;13(10): e1002152.

3. Suvi Karuranga BMPSPS. IDF DIABETES ATLAS. 2019

4. Gauld WR, Lyall A. Tuberculosis as a complication of diabetes mellitus. Endocrinology. 1926;10(5):499.

5. Lönnroth K, Roglic G, Harries AD. Improving tuberculosis prevention and care through addressing the global diabetes epidemic: from evidence to policy and practice. Lancet Diabetes Endocrinol. 2014;2(9):730-9.

6. Baker MA, Han X, Wang Q, Wang Y, Cai J, Ma Y, et al. The impact of diabetes on tuberculosis treatment outcomes: a systemic review. Int J Diabetes Dev Ctries. 2016;36(4):490-507.

7. Stevenson CR, Forouhi NG, Roglic G, Williams BG, Lauer JA, Dye C, et al. Diabetes and tuberculosis: the impact of the diabetes epidemic on tuberculosis incidence. BMC Public Health. 2007:7:1-8.
8. Hayashi S, Chandramohan D. Risk of active tuberculosis among people with diabetes mellitus: systematic review and meta-analysis. Trop Med Int Health. 2018;23(10):1058-70.

9. Jeon CY, Murray MB. Diabetes mellitus increases the risk of active tuberculosis: a systematic review of 13 observational studies. PLoS Med. 2008;5(7):1091-101.

10. Güler M, Ünsal E, Dursun B, Aydin Ö, Capan N. Factors influencing sputum smear and culture conversion time among patients with new case pulmonary tuberculosis. Int J Clin Pract. 2007;61(2):231-5.

11. Faurholt-Jepsen D, Range N, Praygod G, Jeremiah K, Faurholt-Jepsen $M$, Aabye $M G$, et al. Diabetes is a strong predictor of mortality during tuberculosis treatment: a prospective cohort study among tuberculosis patients from Mwanza, Tanzania. Trop Med Int Health. 2013;18(7):822-9.

12. Tong $X$, Wang $D$, Wang $H$, Liao $Y$, Song $Y$, Li $Y$, et al. Clinical features in pulmonary tuberculosis patients combined with diabetes mellitus in China: an observational study. Clin Respir J. 2021;15(9):1012-8.

13. Mave V, Gaikwad S, Barthwal M, Chandanwale A, Lokhande R, Kadam D, et al. Diabetes mellitus and tuberculosis treatment outcomes in Pune, India. Open Forum Infect Dis. 2021. https://doi.org/10.1093/ofid/ofab0 97.

14. Restrepo BI, Schlesinger LS. Impact of diabetes on the natural history of tuberculosis. Diabetes Res Clin Pract. 2014;106(2):191-9.

15. Federation ID. Global guideline for type 2 diabetes. 2012.

16. Holden IK, Seersholm L, Wejse A, Johansen IS. Predictors for pulmonary tuberculosis treatment outcome in |||||||| OPEN. www.nature.com/scien tificreports.

17. Charlson M, Szatrowski TP, Peterson J, Gold J. Validation of a combined comorbidity index. J Clin Epidemiol. 1994;47(11):1245-51.

18. https://diabetes.dk/presse/diabetes-i-tal/diabetes-i-danmark.aspx.

19. Kamper-Jørgensen Z, Carstensen B, Norredam M, Bygbjerg IC, Andersen $\mathrm{PH}$, Jørgensen ME. Diabetes-related tuberculosis in Denmark: effect of ethnicity, diabetes duration and year of diagnosis. Int J Tuberc Lung Dis. 2015;19(10):1169-75.

20. Jiménez-Corona ME, Cruz-Hervert LP, García-García L, Ferreyra-Reyes L, Delgado-Sánchez G, Bobadilla-Del-Valle M, et al. Association of diabetes and tuberculosis: impact on treatment and post-treatment outcomes. Thorax. 2013;68(3):214-20.

21. Zheng C, Hu M, Gao F. Diabetes and pulmonary tuberculosis: a global overview with special focus on the situation in Asian countries with high TB-DM burden. Glob Health Action. 2017;10(1):1264702.

22. Pande T, Huddart S, Xavier W, Kulavalli S, Chen T, Pai M, et al. Prevalence of diabetes mellitus amongst hospitalized tuberculosis patients at an Indian tertiary care center: a descriptive analysis. PLOS ONE. 2018;13(7): e0200838.

23. Araia ZZ. Diabetes, metabolic syndrome and obesity: targets and therapy Dovepress open access to scientific and medical research. 2021. https:// www.dovepress.com/terms.php.

24. Kumar Nathella P, Babu S. Influence of diabetes mellitus on immunity to human tuberculosis. Immunology. 2017;152(1):13-24.

25. Sane Schepisi M, Navarra A, Altet Gomez MN, Dudnyk A, Dyrhol-Riise AM, Esteban J, et al. Burden and characteristics of the comorbidity tuberculosis-diabetes in Europe: TBnet prevalence survey and case-control study. Open Forum Infect Dis. 2019. https://doi.org/10.1093/ofid/ofy337.

26. Omar N, Wong J, Thu K, Alikhan MF, Chaw L. Prevalence and associated factors of diabetes mellitus among tuberculosis patients in Brunei Darussalam: a 6-year retrospective cohort study. Int J Infect Dis. 2021;1(105):267-73.

27. Kruse A, Hvass AF, Wejse C, Andersen ÅB. Tuberkulosebekæmpelse i Danmark Et nationalt tuberkuloseprogram Indholdsfortegnelse. 2018;2018:1-86.

28. Nakorsaaneqarfik N. Notat Smitsomme sygdomme i Grønland 2018. 2019.

29. Larsen CVL, Hansen CB, Ingemann C. Befolkningsundersøgelsen i Grønland 2018. Levevilkår, livsstil og helbred. 2019. 62.

30. Byberg S, Soborg B, Andersson M, Bjerregaard P, Jørgensen ME. Diabetes is a risk factor for tuberculosis in the Inuit population of Greenland. Chest. 2012;142(4):877-84

31. Jørgensen ME, Bjeregaard P, Borch-Johnsen K, Backer V, Becker U, Jørgensen $T$, et al. Diabetes and impaired glucose tolerance among the Inuit 
population of Greenland. Diabetes Care. 2002. https://doi.org/10.2337/ diacare.25.10.1766.

32. Jørgensen ME, Pedersen ML. Diabetes i Grønland. Ugeskrift for Læger. 2020;1-7.

33. Rådet for Socialt Udsatte. „I Grønland Er Jeg for Dansk, Og I Danmark Er Jeg 'Bare' Grønlænder" Udfordringer for udsatte grønlændere i Danmark. 2016

34. Rådet for Socialt Udsatte. Jo mere udsat—-jo mere syg Om socialt udsatte danskeres sundhed og sygdom. 2014. 54.

35. Juel K, Davidsen M, Pedersen PV, Curtis T. Socialt udsattes brug af sundhedsvæsenet. Statens Institut for Folkesundhed, Rådet for Socialt Udsatte, Syddansk Universitet. 2010;58. ISBN 978-87-7546-091-5.

36. Langholz Kristensen K, Nørredam M, Lillebaek T, Munk-Andersen E, Ravn P. Tuberkulose blandt asylansøgere. Ugeskrift for Læger. 2018;180:V11170(13):2-5.

37. Strøbaek L, Davidsen M, Pedersen PV. Socialt udsattes dødelighed og brug af sundhedsvaesenet Registeropfølgning 2007-2015. 2017.

38. Jørgensen A. Dysglycaemia among tuberculosis patients without known diabetes in a low-endemic setting. Submitted. 2021.

\section{Publisher's Note}

Springer Nature remains neutral with regard to jurisdictional claims in published maps and institutional affiliations.

- fast, convenient online submission

- thorough peer review by experienced researchers in your field

- rapid publication on acceptance

- support for research data, including large and complex data types

- gold Open Access which fosters wider collaboration and increased citations

- maximum visibility for your research: over $100 \mathrm{M}$ website views per year

At BMC, research is always in progress.

Learn more biomedcentral.com/submissions 